\title{
Modelul teatral englez reflectat în tendințele dramaturgiei românești "douămiiste"
}

\author{
Asist. univ. dr. BOTEZATU Elena \\ Universitatea „Dunărea de Jos” din Galați
}

\begin{abstract}
In what post-1989 drama in the Romanian cultural space is concerned, one of the topics for debate in literary criticism has referred to the concept of "douămiism" (roughly, specific to the 2000s), respectively, to the existence or non-existence of yet another "category" that could be ascribed to this "clipping" of a "generation". In a birdeye view approach, one notes a strong influence of the English pattern in the theatre trends of the "age" in this area of Europe. There is visible preference for particularized structures attached to a type of drama called "alternative, different" or "independent". Such is the case with "violent, reductionist language" which "wears out" taboos in order to deconstruct them, "a genuine verbal artillery" and frequent calques of "lexical paradigms" which once again signal "the overt and reprehensible trend of imitating the Western liberalism".
\end{abstract}

Keywords: post-1989 Romanian drama, English pattern, violent language, Western liberalism

În spațiul cultural românesc, una dintre temele dezbaterilor din sfera criticii literare a vizat conceptul de „douămiism”, respectiv existența sau inexistența - încă - a unei „categorii” care să poată fi încadrată acestui „decupaj” de „generație”. Direcția analitică, deși, poate, aparent surprinzătoare, prezintă „resorturi” mai vechi, după cum o demonstrează și apariția volumului Generația anului 2000. Scenarii de juventologie prospectivă ${ }^{29}$, încă din 1988. Propunând o călătorie imaginară în viitor și încercând să între- / pre-vadă „Scenarii” ce au în centrul lor „Tinerii”, Fred Mahler își situa demersul în rândul studiilor de tip „yester-morrow” (ieri-mâine), subliniind, că „viitorul mileniu nu se mai situează la limita incertă a orizontului, ci începe tot mai mult să constituie prezentul nostru" ${ }^{\prime \prime}$. Argumentarea în care se lansează vizează faptul

${ }^{29}$ V. Fred Mahler, Generația anului 2000. Scenarii de juventologie prospectivă, Editura Politică, București, 1988.

${ }^{30}$ V. și Simona Antofi, General Dictionary of Romanian Literature - Obverse and Reverse Critical Reception, în Oana Cenac (coord., edit.), International Conference of Common 
că „trăgîndu-și rădăcinile din trecut, crescînd pe solul prezentului și urmând matricea acestuia, viitorul pare a fi nu numai relativ cunoscut, dar și aproape complet predeterminat.”. Cu toate acestea, existențele „proiectate" rămân deschise unui „destin” „,încă necunoscut, în care schimbările, chiar radicale și surprinzătoare, sînt și vor fi legea"31. Asemenea, într-un număr al revistei Scena din 1998, „constructul” de "generație douămiistă" era întrevăzut prin topul de stagiune alcătuit din 14 studenți teatrologi ${ }^{32}$, însă numele „câștigătorilor de poziții” nu par a se mai distinge în „continuarea” fenomenului teatral românesc.

Sintagma „generația douămiistă” a determinat o adevărată divergență în rândul opiniilor exprimate fie în paginile revistelor, fie în, ce-i drept, puținele lucrări consacrate acestei „etape literare în tranziție ${ }^{33 "}$. Fără a se mai axa în esență pe deja contoversatul, la rândul său, concept de „generație" ${ }^{\prime \prime}$, polemicile

Vocabulary/Specialized Vocabulary: Manifestations of Creativity of Human Language, 6-7 iunie 2014, volumul MANIFESTARI ALE CREATIVITATII LIMBAJULUI UMAN, 2014, p. 13-19, ISBN:978-606-17-0623-5, Accession Number WOS:000378446400001 și Nicoleta Ifrim, Theoretical Aspects of Identity Discourse in Post-totalitarian Cultures, în Procedia-Social and Behavioral Journal (ISSN: 1877-0428) (ISSN: 1877-0509), vol.63/2012 ELSEVIER, pp.35-40, DOI 10.1016/j.sbspro.2012.10.007, http://www.sciencedirect.com/science/journal/18770428/63/supp/C, WOS:000361477200006.

${ }^{31}$ Ibidem, pp. 5-6. „Viziunea” ulterioară nu mai interesează, întrucât discursul devine compromis politic.

${ }^{2}$ V. revista Scena, nr. 4, Comedia în tristețea tranziției, Anul I, august 1998, pp. 32-33.

33 „Tranziție către... (ce anume?). De la absența unui răspuns la această întrebare ni se trag toate ponoasele", v. Marian Popescu, Scenele teatrului românesc (1945-2004). De la cenzură la libertate. Studii de istorie, critică și teorie teatrală, Editura UNITEXT, București, 2004, pp. 194-208.

${ }^{34}$ De-a lungul timpului, structura "generație de creație / literară" a fost definită în maniere diferite, contestată sau susținută de numeroase „voci”. Se distinge însă „viziunea" lui Tudor Vianu, conform căreia în cadrul aceluiași „val” pot fi inluși scriitori ale căror opere prezintă afinități estetice, valorice. Chiar dacă acest principiu primează, propunem câteva „interpretări” ale conceptului „prin autori”. În subcapitolul Introducere la ideea de generație, Lucian Valea amintea de pătrunderea termenului în filosofia culturală odată cu Dielthey, găsindu-și aplicații „generoase" în scrierile lui José Ortega y Gasset, pentru care „generația” reprezenta „organul vizual cu ajutorul căruia discernem, în autenticitatea sa efectivă și vibrantă, realitatea istorică" sau, nefiind altceva "decât structurarea vieții umane în fiecare moment" (v. En torno a Galileo și Esquema de las crisis). „În istoria artei europene, conceptul e introdus de Wilhelm Pinder (1929); în lingvistică de M. Bahtin - Discursul în roman - (1934-1935), de unde aflăm că: «În fiecare moment istoric al vieții social-ideologice, fiecare generație, în orice strat social, își are limbajul ei, mai mult, fiecare vârstă, în esență ăși are limbajul ei, 
tratează existența sau nu a unei direcții estetice unificatoare „,în epocă”, în texte și autori. Întrucât „bătăliile” au vizat cu precădere poezia ${ }^{35}$ și proza ${ }^{36}$, prezentul demers va încerca extinderea considerațiilor analitice asupra „dramaturgiei cotidianului" ${ }^{37}$, acolo unde se disting similarități.

Tratarea analitică a "douămiismului", s-a realizat (și) în dosarul numărul 3 al revistei Vatra, în cadrul unei abordări critice ${ }^{38}$ ce se dorea a reprezenta un bilanț menit să evidențieze dacă se tratează de (vre)un „fir roșu” al „tendinței literare” în dezbatere, din punct de vedere estetic. Afirmația lui Ion Pop, conform căreia în literatură se constată preferinţa pentru „aspectele rezidual promiscue ale lumii postcomuniste”, în sensul unei „eliberări, al „mizei pe autenticitate, pe o sinceritate necenzurată, cu defulări inevitabil tumultuoase, adesea excesive, de plan primar, atât la nivelul trăirii (realism brutal al universului... imaginar, notaţie a faptului imediat, exterior sau acut biografic,

vocabularul ei, sistemul ei specific de accentuare»", în Lucian Valea, Opere, vol. 6 Generația amânată, ed. îngrijită și revizuită de Mircea Măluț, Editura Limes, 2012, p. 9-11. V. și Mircea Vulcănescu, "Tînăra generație» sau Cine sînt și ce vor tinerii români? (ed. îngrijită de Marin Diaconu cu ocazia împlinirii a 100 de ani de la nașterea autorului), Editura Compania, București, 2004.

${ }^{35}$ V. Daniel D. Marin, Poezia antiutopică. O antologie a douămiismului poetic românesc, Editura. Paralela 45, Piteşti, 2010, antologie despre care Al. Cistelecan afirmă că „ar putea fi una de reper". V. un articol de întâmpinare critică a „,antologiei": Marius Chivu, Douămiism la purtător. Feedbook, în Dilema Veche, Nr. 341 / 25 august, 1 septembrie 2010, disponibil online: http://www.romaniaculturala.ro/articol.php?cod=15444.

36 „Discuţii sau polemici mai vechi sau mai noi, denotă, dincolo de observaţiile sau analizele pertinente, şi o anumită descalificare a dramaturgiei în raport cu evoluția celorlalte genuri literare. Dacă acest lucru i-a iritat de multe ori pe unii dintre oamenii de teatru, faptul în sine nu a condus, cum era de aşteptat, la o examinare lucidă a realităţii domeniului. Iritările de care vorbeam au avut de multe ori ca rezultat o sporită şi păguboasă autarhie a domeniului teatral.", în Marian Popescu, Oglinda spartă. Despre teatrul românesc după 1989. Critică teatrală, polemici, puncte de vedere, Editura UNITEXT, București, 1997, pp. 147-148.

${ }^{37}$ V. Miruna Runcan, Mihai Pedestru, Raluca Sas-Marinescu, Dramaturgia cotidianului. Piese de teatru, scenarii de film, reportaje, interviuri, Editura EIKON, Cluj-Napoca, 2012.

${ }^{38}$ Alex Goldiș, Bilanțul douămiismului, Vatra, nr. 3/2009 (Al. Cistelecan, I. Pop, P. Cernat, S. Cordoș, D. Cristea-Enache, A. Bodiu, M. Iovănel, E. Vlădăreanu, Al. Matei, N. Bârna, C. Komartin, I. Pertaș, B. Burța-Cernat, A. Patraș, C. Ciotloș, F. Ilis, R. Vancu, I. Cistelecan, F. Pârjol, D. Varga, C. Borza, A. Simuț, C. Turcuș), disponibil online: http://www.romaniaculturala.ro/articol.php?cod=12629. 
refuzul poetizării), cât şi al expresiei sale verbale" ${ }^{39}$, întărește faptul că "labirintul” totalitar ${ }^{40}$ a determinat o „cicatrice” încă vizibilă în paginile „noii” dramaturgii, a „noului spectacol”, dar și după ,tragerea cortinei”.

Societatea de consum, „ca organism nivelator globalizant, relativizant şi dezvrăjit, cu uriaşa forţă de informaţie, dar şi de manipulare prin toate formele mass- media" ${ }^{41}$ se răsfrânge în mediul literar, prin „,îndreptarea privirilor către exterior". Astfel, în Structuri și formule de compoziție ale textului dramatic ${ }^{42}$, Alina Nelega, în calitate de critic de teatru, de această dată, explică particularitățile dramaturgiei „douămiiste”, pornind de la cele ale modelului britanic, de la teatrul „in-yer-face” („în-fața-ta”), împrumutând pentru reprezentanți denumirea de „furioși”: „ «Cum poți să-ți dai seama dacă o piesă e in-yer-face»? De fapt, nu e un lucru prea dificil: limbajul e de obicei murdar, personajele vorbesc despre subiecte interzise, își scot hainele, fac sex, se umilesc unele pe altele, resimt emoții neplăcute, devin brusc violente. Teatrul de felul acesta, atunci când e cu adevărat reușit, constrânge publicul să reacționeze: fie spectatorilor le vine să dea buzna afară din clădire, fie că, brusc, sunt convinși, că e cel mai bun lucru pe care l-au văzut în viața lor și vor ca și prietenii lor să-1 vadă. E genul de teatru care ne face să folosim superlative, fie în sens laudativ, fie peiorativ." 43 .

Cristina Rusiecki notează rolul atribuit acestui gen, și anume: „s,ochează publicul prin extremismul limbii și al imaginilor, îl destabilizează prin franchețea emoțională și îl deranjează, punând întrebări acute despre normele morale. Nu numai că însumează zeitgeist-ul (spiritul vremii), dar îl și critică"44.

${ }^{39}$ V. Ion Pop, «Douămiiştii» împlinesc sloganul autenticist-biografist al celor de la '80, în Ibidem.

40, ,...) chiar dacă monstrul din labirint a fost ucis, forma mentală generată de construcția labirintului totalitar în România supraviețuiește încă după 1989", în Marian Popescu, Oglinda spartă. Teatrul românesc după 1989, Ed. UNITEXT, București, seria Eseu, 1997 p. 90.

${ }^{41}$ Alex Goldiș, Bilanțul douămiismului Vatra, nr. 3/2009 (Ion Pop, titlul cit.).

${ }^{42}$ V. Alina Nelega, Structuri și formule de compoziție ale textului dramatic, Cluj-Napoca, Editura Eikon, 2010.

${ }^{43}$ Aleks Sierz, In yer-face theatre: British Drama Today, Faber\&Faber, London, 2001, p. 5, apud. Alina Nelega, Structuri și formule de compoziție ale textului dramatic, Cluj-Napoca, Editura Eikon, 2010, p. 140.

${ }^{44}$ V. Cristina Rusiecki, Cultura, Aleks Seirz și Teatrul In-Yer-Face, apărut pe 9.12.2009, disponibil online: http://revistacultura.ro/nou/2009/12/aleks-sierz-si-teatrul-in-yer-face/. V. și Mihaela Michailov, Interviu cu Orla O’Loughlin: Teatrul trebuie să fie ludic și 
Astfel, se reamarcă „explozia” unor elemente precum: violența, brutalitatea, sadomasochismul, criminalitatea, grotescul, vulgaritatea 45 , trivialitatea, sexualitatea ș.a. De altfel, în aceeași lucrare a sa menționată, și Nelega punctează aceste înclinații tematice, după cum urmează: „Temele preferate de acești autori sunt situate în universuri până nu demult tabuizate de scenă: pornografia, homosexualitatea, bestialitatea - locuri în care spiritul uman este refuzat, iar violența excesivă se demonetizează prin reprezentare repetată. Categoric, genul acesta de dramaturgie este lipsit de compasiune, anti-melodramatic, alienant și astfel se situează (și) în descendența teatrului epic brechtian, prin distanțarea pe care, implicit, violența explicită o provoacă. Autorii in-yer-face folosesc tactici (adesea puerile) de șoc și provocare pentru a trezi publicul și a pune probleme de genul: ce înseamnă normalitatea, umanitatea sau ce e natural și ce este real. Șocul este baza a ceea ce Sierz numește «sensibilitate confrontațională» ${ }^{46}$ sau, ceva mai departe «teatru confrontațional» sau «teatru experiențial». Acesta, ca nouă estetică a anilor '90, după cum consideră același Sierz, urmărește «să trezească publicul și să-i vorbească despre experiențe extreme, adesea cu scopul de a-i imuniza față de evenimente identice din viața reală.»"47. Fără a uita de „limbajul blasfemiator - adevărată «artilerie verbală»", autoarea menționează originile direcției în tragediile antice și în „toată" istoria teatrului englez ${ }^{48}$, asemenea lui Sierz.

Despre influențele modelului britanic, organizând stagii în Europa, în nume propriu sau prin UNITER ${ }^{49}$, Marian Popescu semnala, în rândul tinerilor

șmecher, și Royal Court, profesionalizarea dramaturgului patentat, în Noua literatură, nr. 3, ianuarie 2007, p. 23.

${ }^{45} \mathrm{~V}$. și Grid Modorcea, Ludic, lubric și liturgic sau Înjurătura în teatrul și filmul românesc. Și nu numai, Editura Cartea Românească, București, 2004.

${ }^{46}$ Aleks Sierz, In yer-face theatre: British Drama Today, Faber\&Faber, London, 2001, p. 9, apud. Alina Nelega, Structuri și formule de compoziție ale textului dramatic, Cluj-Napoca, Editura Eikon, 2010, p. 140.

${ }^{47}$ Aleks Sierz, In yer-face theatre: British Drama Today, Faber\&Faber, London, 2001, p. 239, apud. Ibidem, p. 140.

48 „După opinia lui, teatrul in-yer-face are izvoare adânci (...) de la sângeroasele piese istorice shakespeariene, până la vocabularul îndrăzneț al lui Oscar Wilde, și insolența lui Bernard Shaw sau la «teatrul catastrofei» al lui Howard Barker", în Ibidem, p. 141.

49 "Cu alte cuvinte, cînd recenta Societate teatrală îşi arogă statutul de «alternativă» la UNITER, ea lasă să se ințeleagă că UNITER reprezintă «factorul de putere»", în Marian Popescu, Oglinda spartă. Despre teatrul românesc după 1989. Critică teatrală, polemici, puncte 
practicieni de teatru, greu sesizabila „absorbție a informației culturale” (traductibilă în termeni de creație), căci, după cum afirmă, „de multe ori am observat o preluare mimetică a unor procedee sau piese / texte numai pentru că «asta se jocă acum». Alteori, însă, am văzut o prelucrare culturală a influenței fapt care dovedește că goana după succes poate fi compatibilă cu o gîndire proprie asupra actului teatral." ${ }^{50}$. Deși adept al dechiderii culturale ${ }^{51}$ și semnând numeroase pagini despre modele universale, descriind în același tom starea teatrului britanic, în anumite momente, pe care, de altfel, le detaliază, „în criză profundă”, criticul (se) întreabă: „E România pregătită pentru asta?” 52 . Întrebarea sa pare justificată odată cu „urmarea” într-atât de aproape a modelului. Astfel, se dă, într-un fel, răspuns și problemelor pe care le ridică reprezendanții și adepții „noii” literaturi, precum Bogdan Georgescu, Anca Rotescu, Mihaela Michailov, Iulia Popovici și Alina Nelega, în cadrul dezbaterii coordonate de Cristina Modreanu, ce are următorul „argument”: „De aproape 20 de ani se vorbeşte despre «teatru alternativ», «teatru altfel» sau «teatru independent», dar confuzia în ceea ce priveşte sistemul de producție independent există încă, la fel şi mentalitatea conform căreia aceste spectacole nu merită la fel de multă consideraţie precum acelea de pe scenele teatrelor de stat. De multe ori însă, aceste spectacole sunt cele mai inovative, cele mai

de vedere, Editura UNITEXT, București, 1997, p. 145. V. subcapitolul UNITER, în Ibidem, pp. 217-228.

${ }^{50}$ Idem, Scenele Teatrului Românesc (1945-2004). De la cenzură la libertate. Studii de istorie, critică și teorie teatrală, Editura UNITEXT, București, 2004, p. 304. V. Modernitatea second hand.

${ }^{51} \mathrm{~V}$. impresiile autorului în urma dialogului purtat cu Richard Eyre, directorul Teatrului „Royal Court" despre viitorul Teatrului Româno-Britanic de la Bucureşti, în Idem, Oglinda spartă. Despre teatrul românesc după 1989. Critică teatrală, polemici, puncte de vedere, Editura UNITEXT, București, 1997, pp. 51-53.

${ }^{52}$ Idem, Scenele Teatrului Românesc (1945-2004). De la cenzură la libertate. Studii de istorie, critică și teorie teatrală, Editura UNITEXT, București, 2004, p. 313. De altfel, Marian Popescu preciza: „M-am referit pe scurt la contextul britanic al artelor nu ca să arăt că «nici la EI nu e bine», ci ca să scot în evidență faptul că problema subvenționării artelor e o chestiune de politică a partidului de guvernămînt, a Statului, în genere. Oamenii de teatru englezi sunt serios preocupaţi de asigurarea acestui suport material". Ideea este dusă mai departe „în trecut”, pe când Statul, implicat în cultură, știa (cel mai bine) ce să se joace. Aceasta, pentru o apreciere a condițiilor prezentului de către cei nemulțumiți. V. Idem, Oglinda spartă. Despre teatrul românesc după 1989. Critică teatrală, polemici, puncte de vedere, Editura UNITEXT, București, 1997, p. 53. 
curajoase şi cele mai originale şi fac prin asta o serioasă concurenţă teatrului finanţat de stat. Când va recunoaşte lumea teatrală că are nevoie de independenţi?"53.

În prefața cam „înaripată“ a antologiei Compania poeților tineri în 100 de titluri Petru Romoșan - „poet «optzecist» devenit editor «douămiist»...” găsește că: „Lipsa lor de livresc este bine compensată de un cosmopolitism trăit. Sînt curajoși și cu verbul, și cu virgula. Sfidează, provoacă, detestă apăsat, trăiesc pentru sentiment, deși antisentimental. Consumă muzici, alcool și o tehnologie pe care o și abhoră. Ei chiar sînt ai secolului XXI, din codrii Traciei, dar și pretutindenari ${ }^{54}$. Disprețuiesc diplomele și onorurile, altele decît cele care priversc poezia lor. (...) Sînt mîndri de vulnerabilitățile lor și le poartă ca pe niște medalii. În comparație cu ei, optzeciștii sînt, într-adevăr, învechiți. Douămiiștii știu că sînt înșelați, înțeleg cine îi înșală și nu mai dau doi bani pe șmecherii estetizante sau esopice. (...) Dimensiunea etică, interesul pentru social și politic nu sînt deloc neglijate. Sîntem preveniți: tinerii poeți români își vor țara înapoi” 55 . O altă susținătoare a „douămiiștilor”, Alina Nelega precizează că „poeticul și ludicul, ca formă, cruzimea și hiperrealitatea, ca și conținut - sunt cele care definesc noile piese ale începutului de mileniu. La fel ca și în restul Europei, și în România scena se contaminează de imediat, de prezent. (...) Începutul anilor 2000 găsește scena românească mult mai politică decât cu un deceniu în urmă - și nu în sensul intrării în politica de partid, ci al asumării a ceea ce se petrecea pe scenăca având de-a face cu publicul viu, care trăia și respira în sală" 56 .

Pe de altă parte, Marian Popescu, subliniază că „e greu şi să adopți o atitudine olimpiană, ştiindu-se bine că nici Olimpul nu era un loc calm,

${ }^{53}$ Cristina Modreanu, Teatru independent versus Teatru instituţionalizat, în revista Scena.ro, nr. 9, iunie/iulie 2010, disponibil online: http://www.revistascena.ro/performingarts/dezbatere/teatru-independent-versus-teatru-institutionalizat.

${ }^{54}$ V.: Cezar Paul-Bădescu, Interviu cu Saviana Stănescu: "Sunt, de fapt, un străin global", în Adevărul, nr. 980, 1 iulie 2009 și Oana Cristea Grigorescu, Interviu cu Saviana Stănescu: „Cu toții suntem străini globali”, în Ziarul de duminică, nr. 35, 7 septembrie 2007, disponibile online: http://www.romaniaculturala.ro/articole aut.php?cod aut=144. 55 Paul Cernat, În compania douămiiștilor, în Observatorul Cultural, nr. 593, 2011, disponibil online: $\quad$ http://www.observatorcultural.ro/Citeste-articolul*articleID 25905articles details.html.

${ }^{56}$ Alina Nelega, Structuri și formule dramatice de compoziție ale textului dramatic, Editura EIKON, Cluj-Napoca, 2010, p. 184. 
senin.” ${ }^{57}$. Cât privește „linia estetică”, pe lângă semnalarea unei „fugi de prezent” care ar echivala cu o „îndepărtare de sine”, prin ,îndepărtarea de valorile culturale”, în al doilea volumul ce tratează, încă o dată, „schimbarea de optică" ${ }^{58}$ din teatrul românesc, acesta remarca tendința „,necenzurării” expresiei ,- previzibilă, de altfel -", concretizată în „multe trivialități, exces de limbaj sexual sau scatologic", dar și crearea de subiecte sub impactul realității imediate. Direcția teatrului „de azi” i se pare centrifugă, dar în sensul unui „mimetism” „necizelat”, prin „imitație”, după cum însăși afirmă ${ }^{59}$.

Limitând aceste „confruntări” de opinii, în teatrul „douămiist”, în linii mari, geografia tematică ${ }^{60}$ vizează: captivitate versus libertate (dorința de

57 Marian Popescu, Oglinda spartă. Despre teatrul românesc după 1989. Critică teatrală, polemici, puncte de vedere, Editura UNITEXT, București, 1997, p. 141.

${ }^{58}$ Idem, Scenele Teatrului Românesc (1945-2004). De la cenzură la libertate. Studii de istorie, critică și teorie teatrală, Editura UNITEXT, București, 2004, pp.: 194, 207.

59 „La o privire - dar nu grăbită - asupra stării artei teatrului nostru de azi, devine dintr-o dată foarte greu să-ţi formezi un punct de vedere care să scape tendinței de a accentua parțialitatea, partizanatul dubios sau răbufnirea de moment. (...)Unul din punctele de vedere care s-ar putea formula, se referă la activarea unui mimetism: după 1989 s-au produs câteva tentative de emancipare, de dezinhibare a actului teatral, fie la nivel instituțional, fie la nivelul creației propriu-zise, ca reflex al unei recent asumate libertăţi... necenzurate. Rapidele şi frecventele contacte cu teatrul european, în special, au determinat activarea unor procese teatrale într-o manieră bine cunoscută în cultura română: imitația. Ca în întreaga societatea românească, febra, furia comparațiilor s-a întins rapid: orice contact extern a alimentat acest mod al comparației artistului român cu cel străin fără a observa chestiunile de fond privind contextul cultural (...).Discuțiile, demersurile întreprinse acum în legătură cu realizarea Europei unite, scot în evidență un element important: chestiunea identităţii culturale a fiecărei ţări participante la marele acord european. In acest context, teatrul este un inductor foarte sensibil - pentru că are public- al unor mutaţii, evoluţii reieşite din priza de contact a artistului cu vremea sa. Cum în teatru, procesul creației este foarte complicat, nu vreau să spun că numai această priză la realitate sau la real, explică totul. Jocul planurilor temporale - dinamica memoriei, deci- este un fapt fundamental pentru creația teatrală.", în Marian Popescu, Oglinda spartă. Despre teatrul românesc după 1989. Critică teatrală, polemici, puncte de vedere, Editura UNITEXT, București, 1997, pp. 141-142.

${ }^{60}$ Temele abordate în dosarele revistei Noua literatură vizează: Sexul şi literatura (nr. 1), Cine duce literatura română în străinătate (nr. 7), Burse de creaţie (nr. 8), Literatura şi calculatorul (nr. 11), Noua literatură de pe bloguri (nr. 17), Literatura română în străinătate (nr. 18), Scriitorul-cetățean şi scriitorul din turnul de fildeş (nr. 22), Colocviul Tinerilor Scriitori 2009 (nr. 25) etc. 
eliberare a individului fiind, uneori, dusă până la manifestări mai mult decât dezinhibate), conflictul de mentalități, de concepții determină și o teamă a periferiei față de centru și invers iluzia Vestului și înstrăinarea, singurătatea, chiar și în doi, conflictul dintre generații, realitatea socială și politică (teatrul „politic", teatrul documentar/ docu-textul/ „verbatim”, ca metodă de creație -20/20, Roșia Montană - pe linie fizică și pe linie politică -, ale Gianinei Cărbunariu), existența și destinul ființei urbane, pervertirea acesteia, violența ${ }^{61}$, agresivitatea, inclusiv a mass-mediei, orientări sexuale confuze, deșertăciunea mundană (prelungiri și exagerări ale teatrului absurd) etc.

Spațiile predilecte de desfășurare a acțiunii sunt preluate din „imediat” piața de cartier, strada, blocul, apartamentul, clubul, mașina, avionul etc. -, ce devin în (trans)punerea scenică spații „universale /oricare”, spații "goale”, pentru existențe „în căutare de sine". Cu toate acestea, "spectacolul actual” se subordonează, cel mai adesea, unui singur cadru, României. României pe tărâm propriu, sau României exportate, dar „infiltrate sufletește”. Personajele sunt marionete într-o lume ca teatru, „,vorbesc fără să se audă unul pe celălalt, într-o permanentă zbatere aparent haotică" 62 , incapabile de comunicare, aflându-se sub puterea factorilor externi, pe care fie încearcă să o răstoarne prin revoltă, fie o acceptă resemnați. Sintetizând, Iulia Popovici afirma că: „temele, personajele şi situațiile din text vin din realitatea asta absurdă, ridicolă, dureroasă, de aceea strada se integrează în spectacol, iar spectacolul comunică direct cu strada"63.

Limbajul dur, eliberat din chingile convenționalului, reducționist, „uzează” tabuuri pentru a le demonta. Desele calchieri ale unor „paradigme lexicale", frecvent din limba engleză semnalează, încă o dată, „,vădita și blamata tendință de imitare a liberalismului occidental" ${ }^{64}$. Acțiunea scenică se

${ }^{61}$ V. Amin Maalouf, In the Name of Identity. Violence and the Need to Belong, Translated form the French by Barbara Bray, Penguin Books, New York, 2003, disponibil online pe site-ul Library Genesis: http://gen.lib.rus.ec/.

${ }^{62}$ Iulia Popovici, Stop the Tempo/Ultimul stinge lumina, Agenda LiterNet, ianuarie 2004, disponibil online: http://agenda.liternet.ro/articol/685/Iulia-Popovici/Stop-the-TempoUltimul-stinge-lumina.html.

${ }^{63}$ Idem, Interviu cu Gianina Cărbunariu: „Un spectacol low budget, un teatru cu pereți de sticlă", în Observator Cultural, iulie 2007, disponibil online: http://agenda.liternet.ro/articol/5266/Iulia-Popovici/Un-spectacol-low-budget-un-teatrucu-pereti-de-sticla-Sado-Maso-Blues-Bar.html.

${ }^{64}$ V. Mircea Ghițulescu, Manifestele lui Peca Ștefan sau literatura în impas, în Luceafărul de dimineață, nr. $\quad 12 / 9$ februarie 2008, disponibil online: http://www.romaniaculturala.ro/articol.php?cod=9944. 
construiește pe elemente disparate, pe momente decupate care, într-un final, concep un "sens", încercând să (con)ducă spre restructurare, spre o anumită ordine. Această disponibilitate, tematică și stilistică, faţă de metamorfozele lumii, a făcut ca Dan C. Mihăilescu să precizeze în privința tendinței de „aici și acum”, a numitului douămiism, că „Om trăi și-om vedea ce, cum, cine și cât”"65, subliniind astfel că manifestările literare sunt încă în căutarea de sine, în formare, timpul având să fie criteriul esențial cât privește "trăinicia" acestor creații.

\section{Bibliografie}

\section{Volume de critică literară}

Maalouf, Amin, In the Name of Identity. Violence and the Need to Belong, Translated form the French by Barbara Bray, Penguin Books, New York, 2003 (disponibil online pe siteul Library Genesis: http://gen.lib.rus.ec/ ).

Mahler, Fred, Generația anului 2000. Scenarii de juventologie prospectivă, Editura Politică, București, 1988.

Marin, Daniel D., Poezia antiutopică. O antologie a douămiismului poetic românesc, Editura. Paralela 45, Piteşti, 2010.

Modorcea, Grid, Ludic, lubric și liturgic sau Înjurătura în teatrul și filmul românesc. Și nu numai, Editura Cartea Românească, București, 2004.

Nelega, Alina, Structuri și formule de compoziție ale textului dramatic, Cluj-Napoca, Editura Eikon, 2010.

Popescu, Marian, Oglinda spartă. Despre teatrul românesc după 1989. Critică teatrală, polemici, puncte de vedere, Editura UNITEXT, București, 1997.

Popescu, Marian, Scenele teatrului românesc (1945-2004). De la cenzură la libertate. Studii de istorie, critică și teorie teatrală, Editura UNITEXT, București, 2004.

Runcan, Miruna; Pedestru, Mihai; Sas-Marinescu, Raluca, Dramaturgia cotidianului. Piese de teatru, scenarii de film, reportaje, interviuri, Editura EIKON, Cluj-Napoca, 2012.

Valea, Lucian, Opere, vol. 6 Generația amânată, ed. îngrijită și revizuită de Mircea Măluț, Editura Limes, 2012.

Vulcănescu, Mircea, "Tînăra generație» sau Cine sînt și ce vor tinerii români? (ed. îngrijită de Marin Diaconu cu ocazia împlinirii a 100 de ani de la nașterea autorului), Editura Compania, București, 2004.

${ }^{65}$ Dan C. Mihăilescu, Și așa mai departe?, în Viața literară, IV, august 2008-mai 2010, București, Ed. Humanitas, 2011, pp. 163-167. 


\section{Periodice}

*** Scena, nr. 4, Comedia în tristețea tranziției, Anul I, august 1998.

Cernat, Paul , În compania douămiiștilor, în Observatorul Cultural, nr. 593, 2011, disponibil online: $\quad$ http://www.observatorcultural.ro/Citeste-articolul*articleID 25905articles details.html Chivu, Marius, Douămiism la purtător. Feedbook, în Dilema Veche, Nr. 341 / 25 august, 1 septembrie 2010, disponibil online: http://www.romaniaculturala.ro/articol.php?cod=15444.

Ghițulescu, Mircea, Manifestele lui Peca Ștefan sau literatura în impas, în Luceafărul de dimineață, $\quad$ nr. $\quad 12 / 9$ februarie 2008, disponibil online: http://www.romaniaculturala.ro/articol.php?cod=9944.

Goldiș, Alex, Bilanțul douămiismului, Vatra, nr. 3/2009 (Al. Cistelecan, I. Pop, P. Cernat, S. Cordoș, D. Cristea-Enache, A. Bodiu, M. Iovănel, E. Vlădăreanu, Al. Matei, N. Bârna, C. Komartin, I. Pertaș, B. Burța-Cernat, A. Patraș, C. Ciotloș, F. Ilis, R. Vancu, I. Cistelecan, F. Pârjol, D. Varga, C. Borza, A. Simuț, C. Turcuș), disponibil online: http://www.romaniaculturala.ro/articol.php?cod=12629. Michailov, Mihaela, Interviu cu Orla O'Loughlin: Teatrul trebuie să fie ludic și șmecher, și Royal Court, profesionalizarea dramaturgului patentat, în Noua literatură, nr. 3, ianuarie 2007. Mihăilescu C., Dan, Și așa mai departe?, în Viața literară, IV, august 2008-mai 2010, București, Ed. Humanitas, 2011.

Modreanu, Cristina, Teatru independent versus Teatru instituționalizat, în revista Scena.ro, nr. 9, iunie/iulie 2010, disponibil online: http://www.revistascena.ro/performingarts/dezbatere/teatru-independent-versus-teatru-institutionalizat.

Paul-Bădescu , Cezar , Interviu cu Saviana Stănescu: „Sunt, de fapt, un străin global“, în Adevărul, nr. 980, 1 iulie 2009 și Oana Cristea Grigorescu, Interviu cu Saviana Stănescu: "Cu toții suntem străini globali", în Ziarul de duminică, nr. 35, 7 septembrie 2007, disponibile online: http://www.romaniaculturala.ro/articole aut.php?cod aut=144. Popovici, Iulia, Stop the Tempo/Ultimul stinge lumina, Agenda LiterNet, ianuarie 2004, disponibil online: http://agenda.liternet.ro/articol/685/Iulia-Popovici/Stop-the-TempoUltimul-stinge-lumina.html.

Popovici, Iulia, Interviu cu Gianina Cărbunariu: „Un spectacol low budget, un teatru cu pereți de sticlă", în Observator Cultural, iulie 2007, disponibil online: http://agenda.liternet.ro/articol/5266/Iulia-Popovici/Un-spectacol-low-budget-un-teatrucu-pereti-de-sticla-Sado-Maso-Blues-Bar.html.

Rusiecki, Cristina, Cultura, Aleks Seirz și Teatrul In-Yer-Face, apărut pe 9.12.2009, disponibil online: http://revistacultura.ro/nou/2009/12/aleks-sierz-si-teatrul-in-yer-face/. 